\title{
Long-term feeding of whey protein hydrolysates increases skeletal muscle glycogen levels and improves exercise performance in mice
}

\author{
Atsushi Kanda ${ }^{1 *}$, Masashi Morifuji ${ }^{1}$, Jinichiro Koga ${ }^{1}$, Kentaro Kawanaka ${ }^{2}$, Mitsuru Higuchi $^{3}$ \\ From International Society of Sports Nutrition; 7th Annual ISSN Conference and Expo \\ Clearwater Beach, FL, USA. 24-26 June 2010
}

\section{Background}

Recently, our studies have shown that co-ingestion of carbohydrate and whey protein hydrolysate (WPH) is more effective for increasing post-exercise skeletal muscle glycogen content than ingestion of other protein sources (whey protein, casein hydrolysate, or branched chain amino acids). We have also shown that chronic feeding of whey protein increases glycogen contents in skeletal muscle of exercise-trained rats to a greater extent than does casein. To confirm our hypothesis that longterm feeding of WPH is more effective for increasing both muscle glycogen content and exercise performance than other protein sources, we compared long-term feeding of WPH to other protein sources for their effects on skeletal muscle glycogen levels and exercise performance.

\section{Methods}

Male ddY mice were divided into three groups and allowed free access to water and diet containing either whey protein, WPH, or casein for five weeks. During this period, the mice were exercised in a pool five times a week, with exercise performance being measured once a week. On the final day of the five week experiment, the mice were killed for analysis of glycogen content in the gastrocnemius muscle.

\section{Results}

The WPH group showed a significant increase $(p<$ $0.05)$ in exercise performance $(42.35+/-5.11 \mathrm{~min}) \mathrm{com}$ pared with the casein group $(28.47+/-1.96 \mathrm{~min})$. Furthermore, skeletal muscle glycogen levels were higher in the WPH group $(4.42+/-0.24 \mathrm{mg} / \mathrm{g})$ than in

${ }^{1}$ Food and Health R\&D Laboratories, Meiji Seika Kaisha Ltd., 5-3-1 Chiyoda,

Sakado-shi, Saitama 350-0289, Japan

Full list of author information is available at the end of the article either the whey protein $(3.39+/-0.40 \mathrm{mg} / \mathrm{g}, p<0.05)$ or casein group $(2.60+/-0.18 \mathrm{mg} / \mathrm{g}, p<0.01)$.

\section{Conclusion}

These results indicate that long-term feeding of WPH is more effective for increasing glycogen content in skeletal muscle, and improving exercise performance than other protein sources.

\section{Author details}

'Food and Health R\&D Laboratories, Meiji Seika Kaisha Ltd., 5-3-1 Chiyoda, Sakado-shi, Saitama 350-0289, Japan. ${ }^{2}$ Department of Health and Nutrition, Niigata University of Health and Welfare, 1398 Shimamicho, Kita-ku, Niigata, Niigata 950-3198, Japan. ${ }^{3}$ Faculty of Sport Sciences, Waseda University, 135-1 Horinouchi, Tokorozawa, Saitama 359-1165, Japan.

Published: 15 September 2010

\section{doi:10.1186/1550-2783-7-S1-P20}

Cite this article as: Kanda et al:: Long-term feeding of whey protein hydrolysates increases skeletal muscle glycogen levels and improves exercise performance in mice. Journal of the International Society of Sports Nutrition 2010 7(Suppl 1):P20.

Submit your next manuscript to BioMed Central and take full advantage of:

- Convenient online submission

- Thorough peer review

- No space constraints or color figure charges

- Immediate publication on acceptance

- Inclusion in PubMed, CAS, Scopus and Google Scholar

- Research which is freely available for redistribution 